\title{
Alexandra Cuniță \& Coman Lupu (ed.), Neologie, neologism. Concepte, analize, „ROMANICA” 20, Editura Universității din București, București, 2015, 100 p.
}

\author{
Lavinia Ienceanu* \\ Faculty of Letters, "Alexandru Ioan Cuza" University, Bd. Carol I 11, 700506 Iaşi, Romania
}

Pursuing the thought-provoking line of research charted by issues 3 (2010, Las lenguas románicas y la neologia [Neology as Exhibited by Romance Languages]) and 14 (2013, La dinámica del léxico de la moda en el siglo XIX: estudio de neología léxica [The Dynamics of Fashion Vocabulary in the $19^{\text {th }}$ Century: A Study in Lexical Neology]), ROMANICA's $20^{\text {th }}$ issue Neologie, neologism. Concepte, analize [Neology, Neologism: Keyconcepts and Clarifications] (2015) sheds refreshing light on a notorious 'bone of contention': neologisms. Firmly grounded in a sociolinguistics-oriented approach, the issue under review features six coherently structured contributions reflecting the status quo of individual languages such as Romanian, Spanish and French, on the one hand, and of the Romance linguistic family, on the other, and aiming to go with a finetooth comb over, hence provide valuable insight into, the word-class of neologisms viewed as a selfgenerated supply which can be indefinitely tapped into for regenerating languages both from within and from without, as well as for promoting cultures in an age "of instantly available information and of linguistic globalization” (Moroianu, p. 65). Major topic-related issues debated are: the vast array of taxonomically-based theories, lexicographic compilations and language areas approached, multiplyconstrued terms or distressingly vague definitions of the central concept at issue.

The first contribution, Ideologia y diccionario: aspectos de la neología léxica en los inicios de la lexicografía moderna del español [Ideology vs Dictionary: Glimpses of Early Modern Spanish Lexicography], authored by Dolores Azorín Fernández [= D.A.F.], shows how language-unrelated, mainly ideological bias, is more often than not brought to bear on the selection, cataloguing and compilation of lexicographic lists, which inevitably adulterates the socio-pedagogical function assumed, in theory, by any dictionary purporting to incorporate a so-called "shared social memory". When considered from this particular angle, Hispanophone areas stand out as bona fide bulwarks of purism and Iberocentrism, an attitude staunchly adhered to by DRAE (Dictionary of the Spanish Royal Academy) to this day. The both diachronically- and synchronically-based indepth analysis conducted by D.A.F. on occurrence of various lexical items has yielded a most interesting finding, namely, that unlike more recently compiled descriptive dictionaries such as DEA and vox, most apt to not only adopt, but also to orthographically assimilate foreign words, the language-norm-enforcing authority in Spain exerted over the decades a preeminently restrictive influence by being consistent in reacting unfavourably to neologisms-whether borrowed or newly coined-, and hence by being rather tardy in including them in their latest editions, long after most of the new lexemes had already been listed in the above-mentioned common-use dictionaries. Though embracing a conservatism which promotes formal style to the detriment of colloquial use, as D.A.F. tentatively suggests, with RAE (Spanish Royal Academy) extreme purism-as displayed in 2001, for instance, when vocabulary items pertaining to the peninsular dialect became regular entries of RAE's dictionary, with implicit sanctioning by standard language use as an unequivocal concomitant thereof, in sharp contrast to Hispano-American 'upper-class' lexemes, which were disobligingly denied both of the above privileges-, is, paradoxically enough, converted on occasion into its exact opposite, i.e. extreme permissiveness, as exhibited in an updated version of

\footnotetext{
*Email address: lavinia.ienceanu@yahoo.es.

${ }^{1}$ Lavinia Ienceanu's [= L.I.] translation of Sp. memoria social compartida, Luis Fernando Lara, Teoría del diccionario monolingüe, 1997, p. 94-65 apud D.A.F., p. 8.
} 
the same dictionary, where an influx of "unadulterated borrowings" (p. 18) cannot but "clash" (p. 18) with their native equivalents.

The very fact that the terms are neither mutually exclusive nor cognitively synonymous is the main generator of conflicting views held by proponents of the 'neologism'- and those of the 'new creation'labels, respectively. "Neologisms, newly coined words, neological meanings gather or are strung together, bouncing around in a wild race" (p. 27) in both everyday life and the media, in particular-one of the key-promoters of neologisms, to give credit where it is due-, as Alexandra Cuniță [= A.C.] contends in her Neologisme? Cuvinte recente? [Neologisms? Newly Coined Vocabulary Items?]. With some of the oldest "neologisms" listed verging on two hundred years and, in addition, with "cartof" and "computer" identically labeled in Romanian state-of-theart dictionaries, the author further claims that " $n e o$ logisms and newly coined lexical items could best be viewed as two distinct points on a time continuum" (p. 33). It is equally true, however, that chronologywhich has mainly to do with the inventories made at regular intervals of the new lexical additions to a living language, and the subsequent insertion of these additions into dictionaries of neologisms or newly created lexical items ${ }^{2}$-is not the only criterion resorted to in distinguishing between the two concepts. As corroborative evidence, A.C. adduces the straightforward fact that prior to becoming neological entries in complete language dictionaries, all "newly coined vocabulary items" can be most conveniently treated as "neologisms" pertaining to a certain Romanian functional variety, while additionally remarking that, with all due respect for the three distinct meanings which research of this language area has come to attach to both neologisms and newly created words-i.e., borrowing from another language; lexical item newly created from elements already in use in the same language; new meanings acquired by an older lexeme- "neologisms are first and foremost borrowings from other languages, whereas newly coined lexical items are first and foremost new vocabulary items created from elements already in use in the same language" (p. 26). Taking into account these highly idiosyncratic forces at work in augmenting the semantic-cum-stylistic toolkit of the language, A.C. appositely concludes her plea with three most legitimate claims: that neologisms are conceptually operative only when synchronically approached; that a clear distinction should be made between loan words and loan translations, as well as between grammatical and semantic neology; and last but not least, that even before neologisms are lexicographically attested, a quality-related criterion should be established, with the aim of raising speakers' awareness towards correct employment of these lexical items which, by no means intended to condone elitism or pretentiousness, should more likely be viewed as conducive to more effective, gap-free communication.

Admitting that borrowing is constantly tapped into as a major resource for building up vocabulary, François Gaudin [= F.G.], in her La néologie n'est ce quelle était [Neology Is No Longer What It Used $\mathrm{To} \mathrm{Be}$ ], alerts readers to the danger of a too frequent recourse to it-as fervently advocated by "linguistic liberalism"-, with language asthenia in its aftermath. The author also maintains that, in a language which is equally inherited and re-created, with the passing of time neologisms should best be viewed as located in the borderland separating each of the terms in Saussure's famous dichotomous pairs below from its specifically contrasting counterpart: signifié vs significant, langue vs parole, diachrony vs synchrony, paradigmatic vs syntagmatic. Along the same line of reasoning, just as an originally misused lexical item can be subsequently included under pressure from popular usage in the mainstream vocabulary of a given language, so do neologisms-which as a matter of fact cease to be considered as such after their inclusion therein-,while additionally proving André Martinet's "dynamic synchrony” concept ${ }^{3}$ as tenable as ever. Chopping logic even further, since they were primarily generated as part and parcel of a cultural context, neologisms are of necessity invested with the ability of pointing both ways, i.e. back into the past, and forward into the future, with the added disadvantage that they cannot break free of the linguistic elements which stand in syntag-

\footnotetext{
${ }^{2}$ The author of the article lists the following dictionaries of newly coined words in her References section: Florica Dimitrescu (coord.), Alexandru Ciolan, Coman Lupu, Dicționar de Cuvinte Recente, $3^{\text {rd }}$ edition, Logos, București, 2013; Maria Dumitrescu, Dicționar de cuvinte recente, Semne, București, 2009; Dicționar de cuvinte recente, Semne, București, 2012.

${ }^{3}$ De la synchronie dynamique à la diachronie, "Diachronica", issue 1, 1984, p. 53-64, CrossRef, apud F.G., p. 38.
} 
matic relation to them. F.G. then deems important to distinguish between exogenous neologygenerated through interaction of language codesand endogenous neology — created through recourse to language-internal word-formation devices, with a major focus on abbreviation, apocope, aphaeresis and portmanteau-words. A still further distinction submitted to the reader's attention is that which must be drawn between the type of neology defined in terms of attestation of the lexical item at issuewhere "the attestable neologism is not in production yet, hence not in use either, but can be appropriately documented"-and the type of neology defined in relation to the particular circumstances leading to the creation of a new lexical item - where "a borrowed neologism is, more often than not, anything but new", since it had already been around for some time in a different language community, "a rather puzzling aspect of a linguistic item for which recency of creation is the key phrase". Extrapolating from the findings yielded on French, F.G. raises in the final section the pertinent question of whether neology is still perceived nowadays as being productive and functional worldwide, only to reach the sad conclusion that "neology is no longer what it used to be", and that the constantly shifting borderline between non-linguistically-based neology-which is called on to provide a linguistic expression pointing at a particular entity in the real or conceptual worldand linguistically-based neology-which makes a substantive contribution by extending the expressive resources of a language-only contrives to fudge the issue.

As if endeavouring to bear out the claims made by previous contributors, in his comparative approach to the position assumed in theory and practice by neologisms as exhibited by Romance languages ( $\mathrm{NeO}$ logism de sute de ani sau imprecizie conceptuală? [AgeOld Neologisms or Blurred Concepts?]), Coman Lupu's [= C. L.] stance on the topic at issue further exposes the neologism as a rather ineffectively performing "pseudo-concept" ${ }^{4}$. As Florin Marcu ${ }^{5}$ puts it, C.L. argues, "any scholarly loan word of Latin or Roman origin, or descended from other culturally influential modern languages, can be viewed as pertaining to the class of neologisms. Some of these words, however [...] have been around in Romanian for more than two hundred years [...]. Neologism, therefore, is taken [by the lexicographer] to denote the same thing as the scholarly borrowing, regardless of when it actually entered the receiving language". Equally puzzling is the case of the Spanish term sicario, which acts as additional supporting evidence for Spain's linguistic inhibition against foreign elements, previously discussed by D.A.F. in the opening contribution. And indeed, while making its way into Spanish dictionaries as late as the close of the $19^{\text {th }}$ century, sicar astonishingly dates back in Romanian to as early as the first half of the $17^{\text {th }}$ century-1648, to be more precise-, and with no 'scholarly borrowing' label attached, at that. Now then, it is common knowledge that under the sway of the French Academy-the originator of the long celebrated neology is an art, neologism - an abuse (apud C.L., p. 50)—, many a researcher in the field was more inclined to carry out rough estimations for tracking such words down diachronically or to pin them down as "novel creations' rather than simply record them as neologisms. To compound the difficulty, French linguists tend to define as 'neological' only those lexical items which, though not listed as dictionary entries, carry instead the label sans dictionnaire fixe ${ }^{6}$. It follows from the above that the "novelty" thought to inhere in a word, meaning or construction is nowadays as prone as ever to defy accurate assessment, demarcation or rendition by instrumental techniques or any other battery of linguistic devices in current use. Which in turn just goes to emphatically prove that the term 'neologism', occasionally taken to mean "novel creation"defined through common recourse to one or all of the following criteria: chronology, frequency, areas of diffusion - is apt to vary widely in meaning, and hence give rise to immensely fruitful, if long drawnout controversy.

There are different kinds of neologisms, Cristian Moroianu [= C.M.] argues in one of the most rigorously documented articles of the present issue, Neologismele limbii române între tradiție, modernitate și actualitate [Romanian Neologisms: Traditional, Modern and Present-Day Views], where the reader readily discovers quite a few of the subtopics dealt

\footnotetext{
${ }^{4}$ Cf. Alain Rey apud F.G., p. 37.

${ }^{5}$ See Marele dicționar de neologisme, $10^{\text {th }}$ edition (revised, augmented and updated), Editura Saeculum Vizual, București, 2008.

${ }^{6}$ Alexandra Cuniță apud C.L., p. 50.
} 
with and ideas ventilated in the contributions previously reviewed. Resuming, therefore, Romanian has been found to "distinguish assimilated and morphophonologically unassimilated neologisms, terminological neologisms, international neologisms $[\ldots]$, neologisms displaying single- or multiple etymology, short-lived or long-lived (and productive, at that), discipline-specific or transdisciplinary, neologisms with a single standard variant or several distinguishable variants $[\ldots]$ ”. Approaching the topic from a different angle, one can find "words that came into the language at a rather early point in time [...], but have nevertheless remained unassimilated and are still perceived as intruders by native speakers [...], while there is also the case of fairly recent borrowings which have been readily and successfully assimilated [...]", and are now in general use with Romanian speakers. After painstaking research conducted on elaborate classification of neologisms - with respect to both the word-class to which they belong and the etymological type to which they are assigned (see p. 54-55) - , as well as subsequent analysis of sense relations such as synonymy, antonymy, paronymy, polysemy, semantic and etymological doublets, etc, usually considered to be the main reasons for including them in the language, C.M. deems appropriate to advance the distinction between novel lexical items and neologisms, with the latter further subdivided into: old-fashioned: words pertaining to the "upper-class" variety, which, admittedly, still comply with the canonical chronological criterion, but are no longer in current use; modern/current neologisms: terminological neologisms, pertaining to the standard language variety, their low vs high frequency and small vs large number being indicative of the educational and cultural standards of Romanian society at large; and recently adopted or presentday neologisms: those which, taken over quite recently, have not been in the languge long enough to be properly assimilated. More importantly even, the author further distinguishes between modern neologisms in general current use and the so-called "neonyms". Since "the transition from one stage to another in the political, economic and cultural progress which society is undergoing [...] draws in its wake a concomitant change in categorial membership, from "foreignisms" (partic. words of Greek, French and English origin) through "upper-class" words to neologisms, i.e. terms being currently used by cultivated, civilized speakers", C. M. aptly remarks, we have every reason to believe that the phrase "oldfashioned" neologisms must not be rigidly construed as a contradiction in terms when used of borrowings denoting genuinely new things or social facts at the time when these words were included in the language, which over the years inevitably became outof-date. To put it differently, neologisms tend to go out of use at exactly the same rate as the things in the non-linguistic world they refer to are going out of fashion. Yet the fact remains that "neologisms being in constant, consistent and correct use, and more importantly, by language-conscious speakers, can no longer be dismissed as a mere fad or choice of style. On the contrary, C.M. contends, they must be unmistakably viewed as "a prerequisite for advanced societies, the members of which choose to utilize words that not only reflect modern world standards, but also capture in a most effective, economical and functional manner the opening up of new areas of activity". Nowadays, C.M. claims, "newly coined lexical items are in regular use with common speakers", and "coining (new) words is what common speakers should do on a regular basis". In a final attempt to give the reader linguistically-correct advice, the researcher forcefully argues that, in order for newly created words to be clearly distinguished from bona fide neologisms, the culture-oriented criterion should without fail take precedence over the chronologyoriented one, particularly when considering such a motley array of lexical items as "boschetar", "bunăciune", "ciocoflender"; "alogen”, "apolinic", "bromhidroză", "ecosistem", "fitofag", "inamic", "morgă”, "paneuropean" a.s.f..

The last and most ample contribution in the issue under scrutiny zooms in on Spanish semantic neologisms. More precisely, in her Cuestiones en torno al tratamiento de los neologismos semánticos: entre la intuición, el análisis lingüistico y el diccionario [Issues Raised on Approaching Neologisms Aided by Intuition, Linguistic Analysis or the Dictionary], Antonia Martínez Linares [= A.M.L.] minutely investigates the fascinating subclass of verbs which have been metaphorically shifted into other meanings, such as pilotar, devorar, morder, digerir, engullir, fagocitar, absorber, anclar, agrietar(se), resquebrajar(se), acarrear, derrumbar, dolarizar(se), i.e. of verbs cur-

\footnotetext{
${ }^{7}$ Bălan-Mihailovici, 2005 apud C.M., p. 59.
} 
rently used precisely because they fill in a stylistic gap, but nonetheless failed to be officially listed as carriers of the newly acquired non-literal meaning(s), or of which the meanings listed are incomplete, or, if anything, of which the meanings listed by some dictionaries are fairly dissimilar to the meanings recorded by other equally reliable lexicons. Undertaking the difficult task of conducting a qualitative analysis apt to provide more valuable insights than an ordinary listing of lexical entries usually does, A.M.L. sheds revealing light on the dilemma facing lexical semantics in the Hispanic area when forced to pinpoint such specific conceptualizing means which, though, or paradoxically enough, on account of looking so typologically natural, are most likely to go unnoticed. Compared with the prior knowledge required by skilful labelling of overt neologisms, A.M.L. further argues, identification of the semantic (covert) type is additionally and exclusively dependent on both preexisting context and empirical assistance from a good sense and command of language, as well as from "mastery of vocabulary and neological intuition" "of the speaker, to wit, from an innate agudeza mental ("sharpness of mind"). Even if keeping an embarrassingly low profile among dictionary entries, whether "intensionally" or extensionally defined, A.M.L. maintains, the semantically and stylistically productive techniques developed of appealing to newly acquired connotations of already existing lexical items is a linguistic reality to be reckoned with. After surveying various types of "metaphorical mapping" as displayed by Spanish idiosyncratic collocations, as well as synonymical analogies effecting the semantic associations between the two, the distinguished researcher deems safe to infer that, far from inviting mordant criticism on account of massive arbitrariness, the numerous metaphorical extensions which semantic neology currently boasts have been found to strongly correlate with certain syntagmatic patterns which can and should be more closely studied by prospective research.

In light of the above, and, furthermore, taking into account indisputable fortes such as the vast array of concepts delineated, the pragmatically-based approach adopted, the rigorously documented investigation conducted, and above all, the highly revealing and original insights provided, we consider that the issue reviewed makes a significant contribution to present-day sociolinguistic research, while additionally proving judicious deployment of neologisms, which best reflect a multifaceted, ever-changing linguistic reality, to be the most effective lexical weapon in the hands-and minds-of educated, languageconscious speakers.

[Translated into English by Gina Măciucă]

\footnotetext{
${ }^{8}$ Cf. Blanco, 2012 apud A.M.L., p. 75.

${ }^{9}$ Those capturing "distinctive or prototypical or primary semantic features describing the core meaning" (as translated from Spanish into Romanian by L.I.), cf. Romero, 2008 apud A.M.L., p. 83.
} 